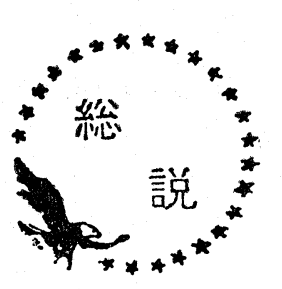

1. はじめに

わが国に和ける一次エネルギー事情の特徴は, 需要 の増大が著しい, 石油への依存度が大きい,エネルギ 一源が石炭から石油への転換により輸入依存度が大き いなどがあげられる。エネルギー消費構造の特徵も， 民生用に比較して工業部門に和ける比率が高く, アメ リカ， E C 諸国などと異なった動きを示している。 従ってわが国は, 一次エネルギーの海外依存度がもっ とも高い国となっている。

一次エネルギーの $86 \%$ を海外よりの輸入に仰ぎ，こ れを利用し加工して付加価值をつけて目覚しい経済発 展を遂げてきたわが国であったが，1973年末の世界的 な石油ショック以来, あらためてわが国に和けるエネ ルギー問題の重要性とその対策の必要性を強く認識す るに至ったことはまだ記憶に新しいところである。

エネルギー危機以来, わが国を始めアメリカ, ドイ ッ,イギリスなど世界各国に杼いて, 石炭利用の見直 しが注目され，技術開発が積極的に推進されるように なってきたが，これは石炭資源が世界的広範囲に広 く分散して分布していること, 石油を始め他の化石燃 料に比較して埋蔵量が豊富であることなどの理由によ る。特にアメリカでは1973年11月にエネルギー独立計 画を公表しているが，代替エネルギー開発の重点を国 内に豊富に埋蔵する石炭の利用に置いている。

国内に産出するエネルギー資源泛しいわが国とし ては，エネルギー対策に和のずから異なる事情がある が，現在1974年 7 月よりサンシャイン計画の一環とし て太陽, 地熱, 水素エネルギーの開発ととるに, 石炭 エネルギーの開発が,ナショナルプロジェクトとして 2000年を目標に息の長い技術開発が推進されている。

石炭は炭素, 水素, 酸素を主体とする有機質の固体 であるが，成因上若干の無機物を含有するので，從来 に和けるごとく、これをそのままの形でエネルギー利 用するのではなく，ガス化，液化などの手段により流 体化し気体や液体燃料に転換するとともに，これらの 処理過程に扔いて環境保全上問題となるばいじん, $\mathrm{SO}_{x}, \mathrm{NO}_{x}$ などの発生をできるだけ減少しらるよう
にクリーン化してクリーンフューエルとして利用する ことが望ましいわけである。

最近各国で注目されている石炭よりの高カロリーガ スの製造, ガス化発電拉よび溶剤処理炭などの製造技 術の開発はいずれも流体化の一つに該当している。す なわち現在の石油, 天然ガスを中心とする流体エネル ギーの消費構造の中に組み込みらるような形飞持って いくための技術開発が中心的な姿になっているとい光 よう。もちろ几直接燃燒法として, イギリス, ドイッ にみられるごとき流動床燃焼炉の開発も必要であらう し, また従来に和けるごとく石炭専焼による石炭火力 や微粉炭と重質油との混合処理物であるコロイド燃料 による石炭火力の再現によるエネルギー対策も当然検 討されるべき問題である。

いずれにしても，わが国は省エネルギー，省資源刘 策, 大量長期備蓄対策はもとより, 進んでエネルギー 資源確保の多様化, 分散化を図るとともに, 資源の有 効利用を図るために, 石炭エネルギーの流体化関連技 術の開発をすならち石炭の再見直しを積極的に進める 必要があることを強調したい。

2. サンシャイン計画とアメリカのエネルギー独立 計画 $^{1) ~ 3) ~}$

2.1 サンシャイン計画

工業技術院より打ち出されたナショナルプロジェク トとしてのサンシャイン計画の概要は表 1 亿示すと招 りで, 2000年を目標に太陽エネルギー, 地熱エネルギ 一, 石炭エネルギー招よび水素エネルギーの開発を図 ろらとするるのである。エネルギー開発に当たっては 国立の研究機関拉よび大学による基礎研究, 委託費に よる関連企業での開発研究などがあるが，それぞれ併 行的炕総合的㳊国民経済の発展と国家安全保障の建前 から推進されるよらな体制が，すなわち 2 軸併行開発 方式が採用され現在に至っている。

石炭エネルギーについては，高カロリーガスを得る ガス化プラントの開発, 低カロリーガス化プラントと これ組み合わされたガス化発電プラント, 複合発電 システムの開発拉よび直按液化, 溶剂抽出液化プラン 
表 1 サンジャイン計画（1974～2000年）

(1)太陽エネルギー

1. 革新的冷暖房システム

1980年頃

2. 小規模発電システム

(10万kW級) 1985年頃

3. 高性能大容量発電システム (100 200万kW) 2000年頃

(2)地熱エネルギー

1. 超樑度地熱発電システム

（10万kW級） 1985年頃

2. 火山発電システム

（30万kW級）1990年頃

(3)石炭のエネルギー

1. ガス化プラント

2. 大容量ガス化プラント

( 5 万 $\mathrm{m}^{3} / \mathrm{d}$ 級) 1980 年頃

3. ガス化発電

4. 液化プラント (100万 $\mathrm{m}^{3} / \mathrm{d}$ 級) 1985 年頃

（20万kW級）1980年頃

( 1 万bbl/d級) 1990年頃

(4)水素エネルギー

1. 革新的製造法

2. トータルシステム)

1985～1990年頃

表 2 サンシャイン計画の開発予算 (昭和 49,50 年度)

(単位：千円)

\begin{tabular}{|c|c|c|c|c|c|c|}
\hline \multirow{2}{*}{ 項 目 } & \multicolumn{2}{|c|}{ 研究開発費 } & \multicolumn{2}{|c|}{ 研究開発委託費 } & \multirow{2}{*}{$\frac{\text { 合 }}{49}$} & \multirow{2}{*}{$\frac{\text { 計 }}{50}$} \\
\hline & 49 & 50 & 49 & 50 & & \\
\hline 太陽エネルギー & 289,744 & 446,251 & 583,713 & 645,000 & 873,457 & $1,091,251$ \\
\hline 地熱エネルギー & 282,742 & 418,849 & 277,708 & 719,567 & 560,450 & $1,138,416$ \\
\hline 石炭エネルギー & 177,800 & 264,153 & 85,000 & 340,200 & $\begin{array}{r}262,800 \\
(172,000)\end{array}$ & $\begin{array}{r}604,353 \\
(253,000)\end{array}$ \\
\hline 水素エネルギー & 232,379 & 319,455 & 99,939 & 144,000 & 332,318 & 463,455 \\
\hline 総 合 研 究 & 46,828 & 90,790 & 148,091 & 159,500 & 194,919 & 250,290 \\
\hline 小 & $1,029,495$ & $1,539,498$ & $1,194,451$ & $2,008,267$ & $\begin{array}{l}2,223,944 \\
(172,000)\end{array}$ & $\begin{array}{l}3,547,765 \\
(253,000)\end{array}$ \\
\hline 調 整 費 & 10,000 & 15,000 & 12,000 & 20,000 & 22,000 & 35,000 \\
\hline $\begin{array}{l}\text { 事業費物よび } \\
\text { 施設整備費 }\end{array}$ & $\longrightarrow$ & & & & 24,056 & 121,332 \\
\hline 合 & - & - & - & 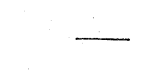 & $\begin{array}{l}2,270,000 \\
(172,000)\end{array}$ & $\begin{array}{l}3,704,097 \\
(253,000)\end{array}$ \\
\hline
\end{tabular}

（）はサンシャイン計画以外の石特予算

トの開発などが，石炭の流体化志向として注目されて いる。もちろん, 合成化学原料, 炭素材料, 電極和よ び製鉄用コークス製造用のバインダーなどへの材料開 発もまた同時に注目されるところである。このほかに エネルギー開発とはやや異なるがプラズマフレームの 超高温を利用したプラズマガス化によるアセチレン， 水素の製造も加えられている。

ちなみにサンシャイン計画の開発予算は表 2 に示す と和りで, 昭和49年度22億7, 000万円, 50 年度 37 億 410
万円で，石炭エネルギー関係はそれぞれ 2 億 6,280 万 円，6億435万円となっている。本年度は総予算46億円 程度が計画されて扣り今後の発展が期待されている。

2.2 アメリカのエネルギー独立計画

わが国とは異なり，豊富なる石炭資源を埋蔵してい るアメリカでは，すでに今日あるを見越していたよう であるが, 1960 年内務省内に石炭研究局 (Office of Coal Research, OCR) を新設し, 従来からある同省 鉱山局 (Bureau of Mines) とともに石炭利用開発を 
一貫して継続的に進めていた。ちなみに当時わが国で は, エネルギーの流体化の波の中で, 石炭のガス化, 液化開発は中断されるに至ったが, 今回のサンシャイ ン計画によってふたたび注目され見直される気運にな っている。

OCR では, 新設当初よりテーマの重点を石炭の液 化法き, 関係会社, 大学に対して委託費を与兄研究 開発を推進している。1969年頃よりは折からの天然ガ ス不足に対処するために，石炭のガス化技術開発の委 託費が液化を上回る状況となり今日に至っている。

最近では1975年1月に OCR, Bureau of Mines, EPA，NSF，NASA などのエネルギー関係の一部を 統合してェネルギー研究開発局 (Energy Research and Development Administration, ERDA)を新設 乙総合的なエネルギー開発を強力に推進している。高 カロリーの SNG（代替天然ガスまたは合成天然ガ ス, Substitute Natural Gas or Synthetic N.G.) 製造に加えて, わが国の対策と同様に低カロリーのガ
ス化拉よびガス化発電が注目されて特り，ふたたび抽 出液化を中心とした石炭の液化, 特に SRC (溶剤精 製炭, Solvent Refined Coal) の製造および 2 次水添 に関する技術開発が注目されはじめている。

アメリカに拈けるエネルギー独立計画を示すと, 表 3,4 のと㧤りで, 省エネルギーとともに石炭のガス 化, 液化などの開発に力が注がれていること，そのほ かには原子力の開発, 新エネルギーとしての核融合, 太陽エネルギー, 地熱エネルギーなどの開発が注目さ れている。また現在 3,700 万bbl/d のエネルギー需要 飞対して, 供給力が 3,100 万bbl/d で 600 万bbl/d の 輸入依存度となっているが, 1980年目標にこれをゼ口 とする，文字通りのエネルギー独立計画が示されてい る。しかし1980年というのは一応の努力目標であっ て,アメリカに括ける全エネルギー資源の海外依存度 を減少させる方向で努力する姿勢にあるといわれてい る。

表 3 エネルギー独立計画 $(1973 \sim 1985)$ 生産・消費目標 （単位：百万bbl/d)

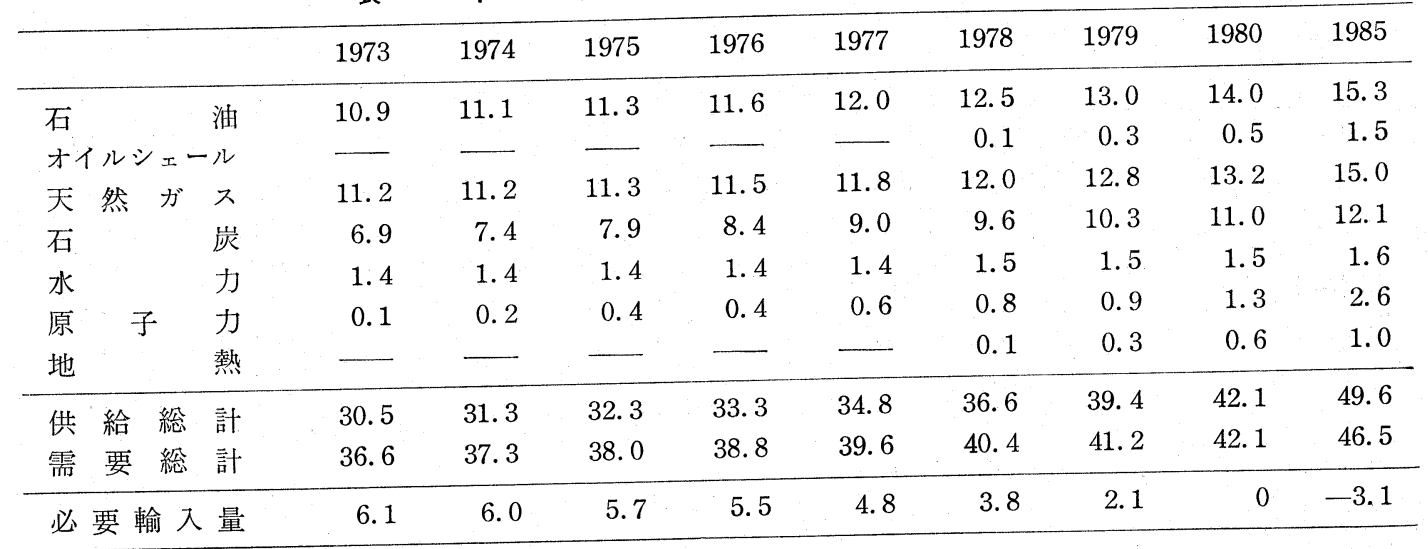

表 4 米国のエネルギー独立計画 （1975～79年100億ドル）

(単位 : 百万\$)

\begin{tabular}{rlr}
\hline 1. & 省エネルギー & 1,440 \\
2. & 国産石油, 天然ガスの増産 & 460 \\
3. 石炭ガス化など & 2,175 \\
4. 原 子 カ & 4,090 \\
5. 新エネルギー & 1,835 \\
& 核融合 & 1,450 \\
& 太陽エネルギー & 200 \\
& 地熱エネルギー & 185 \\
\hline & 合 計
\end{tabular}

表 5 石炭研究予算 (単位: 百万\$)

\begin{tabular}{|c|c|c|}
\hline 項 & 1973年 & 1975年 \\
\hline 採 岸 & 1.7 & 55.0 \\
\hline 採炭の保安 & 28.2 & 27.7 \\
\hline 直接燃焼 & 1.5 & 36.2 \\
\hline ガス化(高カロリー) & 32.5 & 65.3 \\
\hline ガス化(低カロリー) & 4.6 & 50.7 \\
\hline 液 化 & 11.0 & 108.5 \\
\hline 合成燃料 & $\longrightarrow$ & 42.1 \\
\hline アセスメント & 1.0 & 1.9 \\
\hline その他 & 4.6 & 28.1 \\
\hline 計 & 85.1 & 415.5 \\
\hline
\end{tabular}


最近に和ける石炭関係の研究開発予算は表 5 亿示寸 と拉りで，前述したように石炭ガス化開発とともにふ たたび石炭液化にも重点が置かれるようになってきた ことが理解される。

\section{3. 石炭の利用, 流体化}

石炭の利用技術開発に当たっては, 図 1 亿示すよう に種々の利用系統がある114)。いうまでもなくエネル ギーとしての利用もさることながら, 各種原材料とし ての利用開発も同時に必要である。

わが国における石炭利用の現状は, 乾留用, 電力用 および一般燃料用が主体であるが，このほかには僅か に活性炭, フミン酸, 膨潤炭などの製造がある。しか しなんといっても現在は，製鉄業，鋳物業に関連した コークス製造のための乾留工業が主流であることはい らまでもない。ちなみに昭和48年度実績でみると, 国
内炭 2,265 万 $\mathrm{t}$ のらちで乾留用飞 1,000 万 $\mathrm{t}$, 輸入炭 5,800 万 $\mathrm{t}$ のちち 5,430 万 $\mathrm{t}$ が乾留用に使用されて特 り，ほとんど大部分を占めていることが理解される。 石炭は有機質の固体であり, 石炭化度, 石炭組織, 無機物などの差異によって種々異なった性状を示すの で，国内炭はもとより輸入炭を含めて利用，流体化な ぞの技術開発に当たっては, 石炭が持つ基礎的性状, 構造を十分に解明しておくことが重要である。

例总ば石炭と石油之の差異を化学組成上からみると 表 6 のと招りで, $\mathrm{H} / \mathrm{C}$ (原子比) は無煙炭0.3, 高揮 発分藶青炭 0.8 , かっ炭0.7程度であるのに対して, 原 油1.8, ガソリン1.9程度であり, 石炭は石油よりも $\mathrm{H}$ が少なくCが多くかつ他の成分も多い化学的に複雑な 構造を有する有機化合物である ${ }^{5)}$ 。このほかに石炭組 織, 無機物の影響も加味されてくる。石炭化度の差異

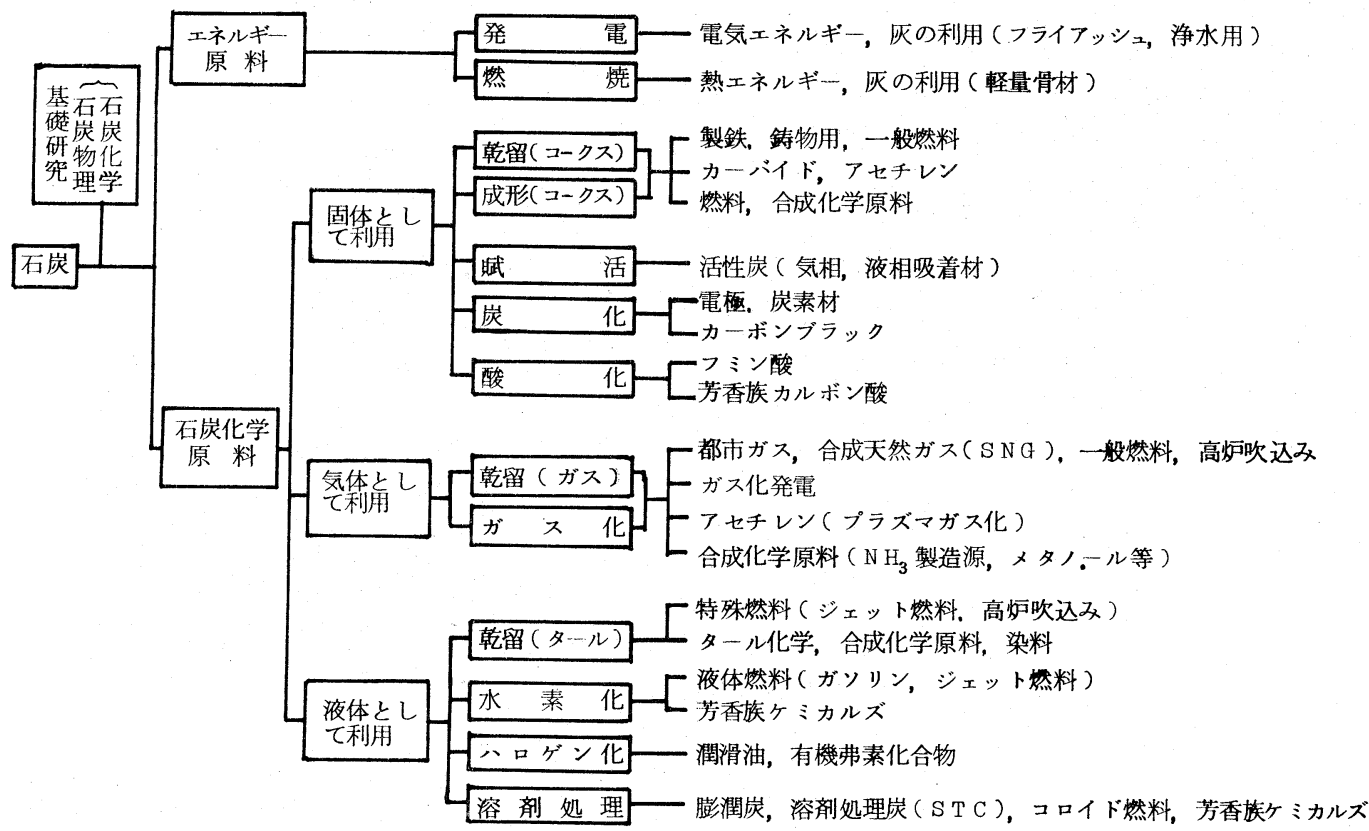

図1 石炭の利用系統図

表 6】!石炭系と石油系の化学組成

\begin{tabular}{lccrrrrrr}
\hline 化学組成 & 無煙炭 & 中揮発分歴青炭 & 高揮発分歴青炭 & かっ炭 & 原油 & ガソリン & トルエン \\
\hline $\mathrm{C}(\%)$ & 93.7 & 88.4 & \multicolumn{8}{c}{84.5} & 80.3 & 72.7 & $83 \sim 87$ & 86 & 91.3 \\
$\mathrm{H}(\%)$ & 2.4 & 5.0 & 5.6 & 5.5 & 4.2 & $11 \sim 14$ & 14 & 8.7 \\
$\mathrm{O}(\%)$ & 2.4 & 4.1 & 7.0 & 11.1 & 21.3 & - & - & - \\
$\mathrm{N}(\%)$ & 0.9 & 1.7 & 1.6 & 1.1 & 1.2 & - & - & - \\
$\mathrm{S}(\%)$ & 0.6 & 0.8 & 1.3 & 1.2 & 0.6 & - & - & - \\
$\mathrm{H} / \mathrm{C}$ (原子比) & 0.31 & 0.67 & 0.79 & 0.82 & 0.69 & 1.76 & 1.94 & 1.14 \\
\hline
\end{tabular}


による水分, 揮発分あるいは微細組織成分, 官能基酸 素, ピリジン抽出量, 粘結性, 流動性, 内部表面積, X線なぞ種々物理的, 化学的性状に差異があること は, 石炭構造の羑異とともによく知られているところ である。徒ってある特定の銘柄炭について開発された 方法,プロセスは，かならずしも他の銘柄炭に適用で きない場合がありらる。

固体である石炭の流体化に当たっては, 石炭の物性 把握のための基礎研究が必要であるゆえんである。

石炭の流体化に和注る主なる項目をあげれば，前述 したように石炭のガス化，液化による気体拉よび夜体 への転換敊よび乾留による副産物があげられるが，こ の泳かに石炭の超微粉础, コロイド然料和よび流動床 燃焼なぞがあげられる。

超微粉研は, 石炭を $200 \mathrm{mesh}(74 \mu \mathrm{m})$ 以下に, でき るだけ微粉砕することによって，見掛上流体として取 り扱いらるようにしたものでパイプ輸送あるいはスラ リー輸送による遠隔地への供給が可能となる。同時に 比重の差を利用することによって，灰分，硫黄分など の無機物の分離が可能となる ${ }^{4}$ 。

ただし火力発電向けにはよいが，コークス工業に拉 いては粘結性低下があるので注意を要する。

コロイド燃料は, 石炭を微粉砕して油と重量比 1 : 1 程度に均一に混合し, これに安定剤を添加して長時 間安定化させたものである。第一次大戦中にイギリス で始めて考案され, わが国でも当時検討されたことが あるが, 最近ふたたびわが国の科学技術庁資源調查会 石炭技術小委員会や電源開発(株)を始めアメリカ, イ ギリスなどで注目されている6。最近では均一混合の 手段に, 熱の利用, 超音波の利用なども考光られから 安定骭もよりよいものが開発されて特り, 現在の技術 をもってすれば比較的容易に製造しうる可能性が高い ので, 石炭と重油との中間をいく燃料として火力発電 および舶用への利用が大いに注目されている。

アメリカでは ERDA よりの委託費によりゼネラル モーターズ社が開発を進めて和り, イギリスではシェ ル系の会社が実施している。わが国では単純に石炭と して輸入するよりも現地でコロイド然料化して輸送す る浪らが，より現実的である上に，ガス化，液化への 原料源としての利用も可能となるので将来をすます注 目されてくるものと思われる。

流動床燃焼は,イギリス National Coal Board の 石炭研究所 (Coal Research Establishment) で開発 が進められているが, 本法はアメリカの Pope Evans and Robbins 社の Packaged boiler と注ぼ同様の直
接燃燒方式で絶型流動床燃焼炉である。流動床中に水 パイプを配置して熱伝導性を高めているので，800〜 $900^{\circ} \mathrm{C}$ の低温燃焼が可能で岁る。従って, 灰の凝結が なくつ $\mathrm{NO}_{x}$ の発生が少ない上に, 石灰石やド口マ イトなどの添加によって，燃焼と同時に 90〜95\% の $\mathrm{SO}_{x}$ の除去も可能であるなど, 現在の環境問題にも 適合した優れた特徵を有しているので,わが国でも注 目されている788)。

結局, 通常の石炭ボイラーに比較して, 炉容積が縮 少され，設備費の低減も可能であるといわれている。 例党ば, 炉容積は $660 \mathrm{MW}$ 級の微粉炭ボイラーに比 較して $1 / 4$ 以下に, $16 \mathrm{~atm}$ 程度の加圧型にすれば 1/7 1/8 以下にすることがでさる。しかし水パイプ の摩耗, 流動床ゆ兄の除塵装置の問題, ドロマイトの 再生方式などいくつかの短所もあり現在開発試験が進 められている段階にある。本法は現在国際エネルギー 機関 (IEA) 飞招いて子採用されて抢り, 世界的な規 模で開発研究が進められようとしている。

\section{4. 石炭のガス化}

\section{1 石炭ガス化の一般的プロセス}

石炭ガス化の一般的なプロセスは図 2 のと扣りで, 前処理, ガス化, ガス変換, ガス精製, メタン化の 5 工程よりなる ${ }^{8)}$ 。

石炭は固体であるので目的, ガス化炉の種類によっ て異なるが， $3 \sim 30 \mathrm{~mm}$ 程度の粉炭あるいは $3 \mathrm{~mm}$ 以 下の微粉炭飞それぞれ粉碎する。粘結炭の場合には $400^{\circ} \mathrm{C}$ 前後の酸化処理あるいは水または油混合による スラリー化などの前処理を行なら必要がある。ガス化 炉では石炭に水蒸気と空気または酸素, 水素とを加兄 てガス化する。この場合に原料である石炭の種類, 灰 の溶融性, 温度, 压力などの反応条件括よびガス化炉 の種類の差異によって種々のガス化反応が起こる。從 って, 与兄られた石炭に最適でありかつどのような種 類のガスを得るか, ガス化目的に合致したガス化炉の 形式選定が重要である。主反応は図 2 (2)で示される水 性ガス化反応であって大きな吸熱反応である。従って この熱の供給方法にもそれぞれ工夫がなされている。

ガス化法には種々の分類法があるが, プロセス別に 分類すると次の 4 種類があげられる。

a）固定床ガス化法 例光ば Lurgi 法（独）

b ) 流動床ガス化法 例 兄ば Winkler 法 (独), Synthane 法, Hygas法(米), 日立法, 三藤法, 石炭技研 法 (日)

c）噴流床ガス化法、例总ば Koppers Totzek 法 


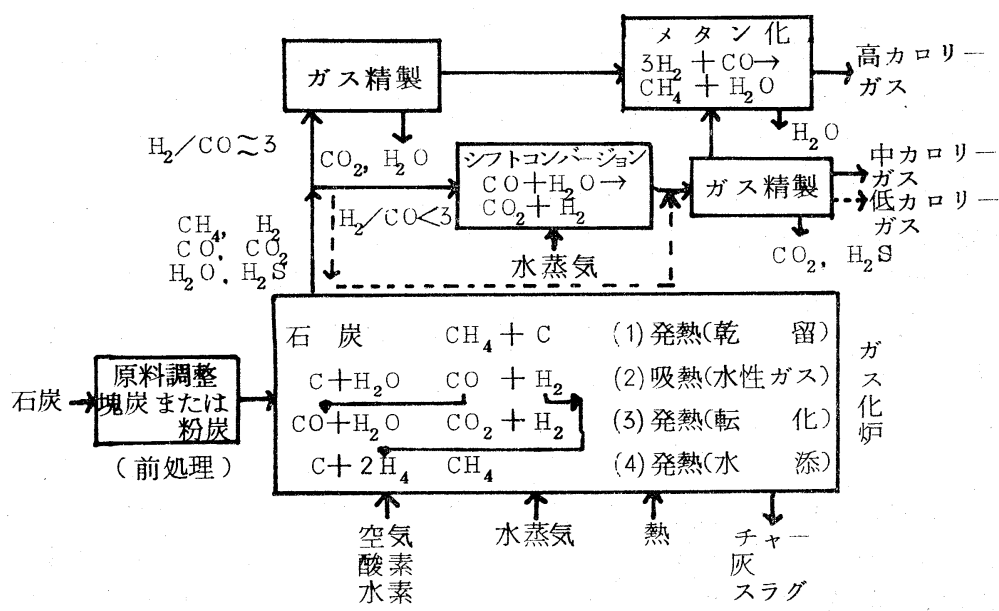

図 2 石炭ガス化の一般的プロセス

(独)

d) 溶融床ガス化法 例总ば Kellogg 法, AT gas 法 (米), 三菱重工法, 新明和 法 (日)

ガス化炉から出た粗ガスは，石炭の種類，ガス化 剤，それぞれのプロセスなどによってガス組成が異な る。 $\mathrm{H}_{2} / \mathrm{CO}$ 比が 3 以下の場合には, ガス変換して図 2 (3)に示される主反応により $\mathrm{H}_{2} / \mathrm{CO}$ 比を 3 以上に 調整してガス精製後, メタン化炉でメタンリッチガス の $8,000 \mathrm{kcal} / \mathrm{Nm}^{3}$ 程度の高カロリーガスとする。 一方 $\mathrm{H}_{2} / \mathrm{CO}$ 比が 3 以上の場合には, 直ちにガス精 製装置にかけて脱炭酸, 脱硫捻よび脱塵を行ない，直 接メタン化炬にかけて高カロリーガスにする。

$1,000 \sim 2,000 \mathrm{kcal} / \mathrm{Nm}^{3}$ 程度の低カロリーガスを得 る場合には，一般に水蒸気と空気，時には一部酸素使 用によりガス化を行なう。得られた粗ガスはメタン化

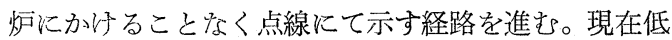
カロリーガスは，これによるガス化発電が注目されて いる。

水蒸気と酸素とによる場合が，ガス化の一般的な形 であるが，この場合には一般に $5,000 \mathrm{kcal} / \mathrm{Nm}^{3}$ 前後 の中カロリーガスが得られる。

ガス化に及ぼす温度, 圧力の影響も一般的に知られ て抢り，粗ガスでメタンリッチとするためには，圧力 を高く温度を低くして加圧がス化する必要がある。

石炭からガスを得るもら一つの方法として，石炭の 乾留が劣る。石炭の高温乾留によるコークス炬ガス は，現在でも都市ガスあるいは合成化学原料など代利 用されていることは周知のと物りで业る。もちろん都
市ガスとして利用する場合には，ガスの燃燒特性はも とよりガス精製が必要であることはいうまでもない。 4.2 高カロリーガス製造技術8 ${ }^{8}$ 13)

アメリカに招いて特に研究開発が盛んである。これ は不足する天然ガス対策として注目されているもの で, 豊富にある石炭を山元付近で加圧下にガス化拉よ びメタン化して高カロリーの SNG を製造しここれを 現在アメリカ国内に縦横に張りめぐらされている天然 ガスのパイプライン網にのせようとする考方方による ๖のである。

現在までに種々のプロセスが ERDA よりの巨額の 委託費によって併行開発されているが，主なるものを あげると次のと呿りである。

(1) Hygas 法 水素添加加圧流 動床 ガス化法で, Institute of Gas Technology が開発中。石炭処理量 $75 \mathrm{t} / \mathrm{d}$, 温度 1 段目 $649 \sim 760^{\circ} \mathrm{C}, 2$ 段目 $870 \sim 980^{\circ} \mathrm{C}$, 圧力 $77 \mathrm{~kg} / \mathrm{cm}^{2}$, ガス生産量 150 万 $\mathrm{ft}^{3} / \mathrm{d}$ 。1970年建設 1, 000万ドル。

(2) Hydrane 法 水素添加加圧流動床 ガス 化法で Hygas 法とは若干異なる。Pittsburgh Energy Research Center(旧 Bureau of Mines の一部) が開 発中。ベンチスチール $2 \sim 10 \mathrm{~kg} / \mathrm{hr}, 700 \sim 900^{\circ} \mathrm{C}, 70$ $\sim 80 \mathrm{~kg} / \mathrm{cm}^{2}, 1973$ 年より研究, 1976年 Morgantown Energy Research Center ヒプラント建設中。

(3) BI gas 法 2 段高温加圧流動床 ガス化法で Bituminous Coal Research 社が開発中。120t/d, 下 部 (1 段目) $1,600^{\circ} \mathrm{C}$, 上部 ( 2 段目) $900^{\circ} \mathrm{C}, 70 \sim$ $100 \mathrm{~kg} / \mathrm{cm}^{2}, 240$ 万 $\mathrm{ft}^{3} / \mathrm{d}, 1975$ 年より建設， 2,600 万ド ル。 
(4) Synthane 法 加圧流動床ガス化法で Pittsburgh Energy Research Center が開発中。75/td, $927^{\circ} \mathrm{C}, 40 \mathrm{~kg} / \mathrm{cm}^{2}, 30$ 万 $\mathrm{ft}^{3} / \mathrm{d}, 1975$ 年 11 月完成試験開 始 1,200 万ドル。

(5) CO gas 法 多段常圧流動床ガス化法で FMC が開発中。COED 法 $(36 \mathrm{t} / \mathrm{d})$ の変形, $100 \mathrm{t} / \mathrm{d}$ 建設 中。

(6) $\mathrm{CO}_{2}$ Acceptor 法：ドロマイト使用の脱 $\mathrm{CO}_{2}$ 加圧流動床ガス化法で Consolidation Coal 社が開発 中。 $40 \mathrm{t} / \mathrm{d}, 830^{\circ} \mathrm{C}, 10 \sim 20 \mathrm{~kg} / \mathrm{cm}^{2}, 200$ 万 $\mathrm{ft}^{3} / \mathrm{d}, 1971$ 年建設, 930 万ドル。

(7) Kellogg 法 溶融塩による加圧溶融床ガス化法 で M.W.Kellogg 社が開発中。ベンチスケール, 炉 径 2 in $\times 3 \mathrm{ft}, 1,000^{\circ} \mathrm{C}, 30 \mathrm{~kg} / \mathrm{cm}^{2}, 1960$ 年より研究。
(8) AT gas 法 溶融鉄による常圧溶融床ガス化法 で Applied Technology 社が開発中。ベンヂスケー ル, 27 in の $2.7 \mathrm{t}$ 溶融鉄炉。1, 400 1, $450^{\circ} \mathrm{C}$, 常圧, 1973年より研究。

研究開発がもっとも進んでいるのは, Hy gas 法, Synthane 法, BI gas 法, $\mathrm{CO}_{2}$ Acceptor 法で, こ のうち前 2 者がもっとも注目されているようである。

例えば Hygas 法は図 3 に示すごとくで, 粉炭は前 処理されるとともに油スラリーとして $77 \mathrm{~kg} / \mathrm{cm}^{2}$ の加 圧ガス化炉中にスラリーポンプによって送入される。 ガス化は 2 段で行なわれるが，水添ガス化により粗ガ スは表 7 のようにメタン含有量が $42 \%$ に達するメタ ンリッチガスを得ている。従って後段の発熱反応であ るメタン化のロードを最小限に止めるようにしたプロ

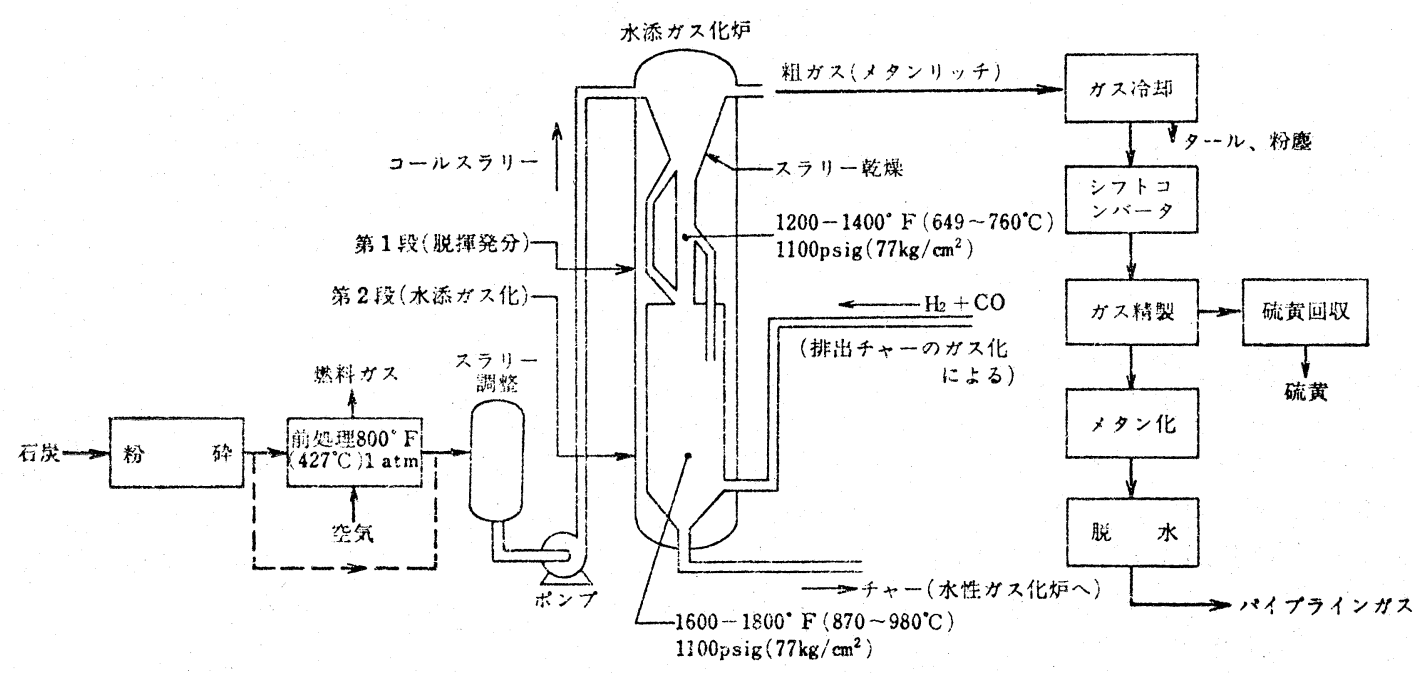

図 3 Hygas 法

表 7 Hygas 法各部のガス組成

\begin{tabular}{|c|c|c|c|c|c|c|}
\hline & \multicolumn{3}{|c|}{ moles $/ \mathrm{hr}$} & \multicolumn{3}{|c|}{$\%$} \\
\hline & 使用水素 & ガス化炉生成ガス & 製品ガス & 使用水素 & ガス化炉生成ガス & 製品ガス \\
\hline $\mathrm{CH}_{4}$ & 40.0 & $8,682.7$ & $9,491.1$ & 0.5 & 42.02 & 93.47 \\
\hline $\mathrm{H}_{2}$ & $7,783.8$ & $2,939.6$ & 450.3 & 97.2 & 14.23 & 4. 44 \\
\hline $\mathrm{CO}$ & 24.0 & 753.3 & 9.0 & 0.3 & 3.65 & 0.09 \\
\hline $\mathrm{CO}_{2}$ & 80.0 & $2,652.3$ & 65.8 & 1.0 & 12.84 & 0.65 \\
\hline $\mathrm{N}_{2}$ & 72.0 & 137.0 & 137.0 & 0.9 & 0.66 & 1.35 \\
\hline $\mathrm{H}_{2} \mathrm{~S}$ & - & 169.0 & - & - & 0.82 & - \\
\hline $\mathrm{H}_{2} \mathrm{O}$ & 8.0 & $5,328.1$ & - & 0.1 & 25.78 & - \\
\hline 計 & $8,007.8$ & $20,662.0$ & $10,153.2$ & 300.0 & 100.00 & 100.00 \\
\hline
\end{tabular}

（注） 1. 原料石炭の揮発分 $31 \%$ ，ガス化率 $53.5 \%$

2. ガス化剂は水素と水蒸気の混合物（水蒸気は $55 \%$ )

3. 製造ガスの総発熱量 $8,650 \mathrm{kcal} / \mathrm{m}^{3}$ 


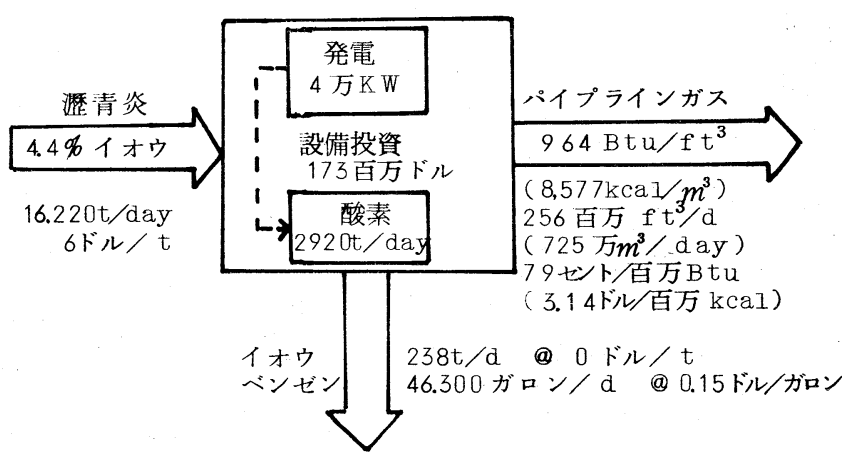

図 4 HYGAS 法の物質収支

パイプラインガス

セント／百万 Btu

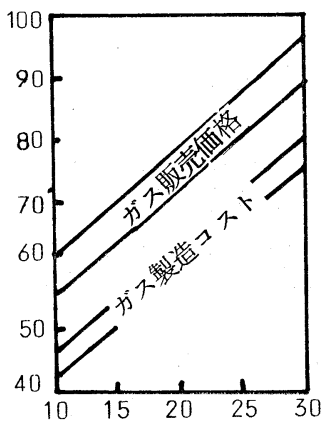

石炭価格, セント/百万 Btu

注：1. 借入金, 自己資金比 65:35

2. 金利 7. $5 \%$

3. 20 年均等償却

図 5 Hygas 法のガス価格 (1972年) 250〜 500 百万 $\mathrm{ft}^{3} / \mathrm{d}\left(\mathbf{7 0 8} \sim \mathbf{1 4 1 6}\right.$ 万 $\left.\mathrm{m}^{3} / \mathrm{d}\right)$ 規 模プラント

\section{表 8 Hygas 法（1974年）}

(1) パイロットプラント

石炭処理量 $75 \mathrm{t} / \mathrm{d}$

建設コスト 1,000 万\$

ガ ス生産量 150 万 $\mathrm{ft}^{3} / \mathrm{d}$

運転人員約 60 名

(2) 商業 炉

建 設コスト 3 億\$

石炭処理量 500 万 $\mathrm{t} / \mathrm{yr}$

パイプラインガス 2 億 5,000 万 $\mathrm{ft}^{3} / \mathrm{d}$

石炭必要量 1 億 2,000 万t(25年間)

運転人員約 450 名

ガス生産さスト $1.15 \$ / 1,000 \mathrm{ft}^{3}$

セスで，現在かっ炭について試験が進められている。

本法の物質収支, 諸コスト, 商業規模でのガスコス
トおよびガスコストに大きく影響を及ぼす石炭価格な ぞについてまとめて示すと図 4,5 , 表 8 のと抽りで ある。

Synthane 法は図 6 に示すと和りで, 構造が簡単 で, 圧力, 温度ともに BI gas 法に比較して低いが, 表 9 にみられるごとく Hygas 法に比較して粗ガスの メタン含有量が $11 \sim 18 \%$ と低い。従って後段のメタ ン化に工夫がなされている。すなわち，パイプまたは 板にラネーニッケルを溶射した特殊な反応管中でメタ ン化させて，メタンリッチの高力ロリーガスを得てい る。この場合に，ガス中の $\mathrm{H}_{2} \mathrm{~S}$ は $0.1 \mathrm{ppm}$ になる うに, 微量硫黄の除去が必要であることが注目され る。本法によるガスコスト試算は表10に示すと挍りで ある。

昨年来日されたDr. Wender 所長の説明によれば, 本法によって生成されるチャーは発電所へ, タールは BTX へ，ガスは Pittsburgh 市へ供給することなど が考えられて㧤り，さらに Fischer Tropsch 合成に より合成油, ケミカルズヘ, メタノール合成によりメ タノールヘ，また空気使用により低カロリーガスを得 てガス化発電へ向けるなどきわめて多目的に使用しう る利点がある方法であることが強調されている5 。

\section{3 中〜低カロリーガス製造技術 ${ }^{8) ~ 13) ~}$}

中カロリーガスの分野では，かつて都市ガスあるい は $\mathrm{H}_{2}+\mathrm{CO}$ の合成原料ガスを得るために，わが国を 始め世界各国に扣いて種々多種の石炭ガス化炉の開発 がなされたことはあまりにも有名である。特にわが国 では Winkler 炉, Koppers Totzek 炉拉よび関係化 学会社に乱いて開発改良された微粉炭ガス化炉などが ある。

最近では低カロリーのガスによるガス化発電が注目 されている。

現在, 世界的に注目されかつ商業炉として活躍して 


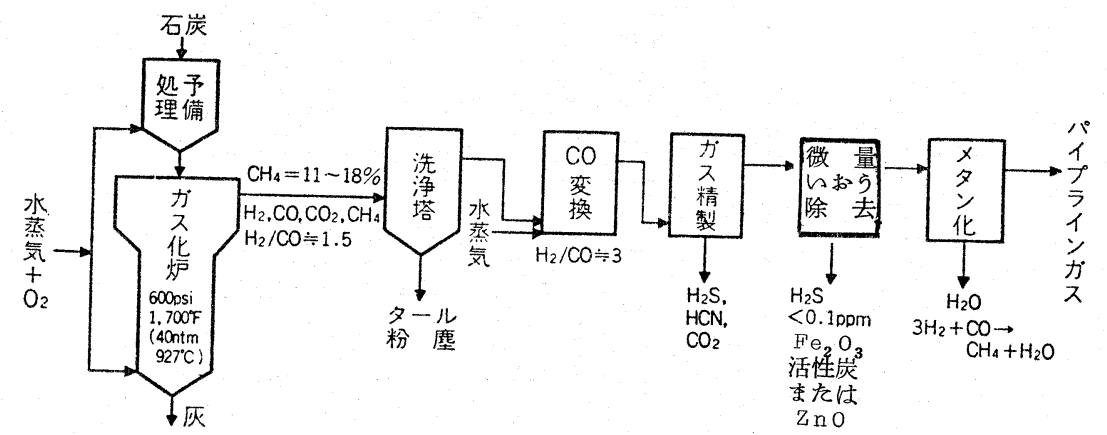

図 6 Synthane 法

表 9 ガス化試験の結果 (Synthane)

\begin{tabular}{|c|c|c|c|c|c|c|}
\hline 柄 & \multicolumn{2}{|c|}{ ピッツバーグ層炭 } & \multicolumn{2}{|c|}{ イリノイ (No.6) 炭 } & \multirow[t]{2}{*}{ かっ炭 } & モンタナかっ炭 \\
\hline C.S.N & $8 \sim 81 / 2$ & $8 \sim 81 / 2$ & $41 / 2$ & $41 / 2$ & & 0 \\
\hline 石炭供給量, $\mathrm{lb} / \mathrm{hr}(\mathrm{kg} / \mathrm{hr})$ & $10.5(4.76)$ & $10.6(4.81)$ & $8.7(3.95)$ & $10.4(4.72)$ & $21.2(9.61)$ & $9.7(4.40)$ \\
\hline 水蒸気/石炭比, $\mathrm{ft}^{3} / \mathrm{lb}\left(\mathrm{m}^{3} / \mathrm{kg}\right)$ & $28 \quad(1.75)$ & $23 \quad(1.44)$ & $34 \quad(2.12)$ & $28 \quad(1.75)$ & $14 \quad(0.87)$ & $26 \quad(1.62)$ \\
\hline $\mathrm{O}_{2} /$ 石炭比, $\mathrm{ft}^{3} / \mathrm{lb}\left(\mathrm{m}^{3} / \mathrm{kg}\right)$ & $7.6(0.47)$ & $4.9(0.31)$ & $7.6(0.47)$ & $3.9(0.24)$ & $3.4(0.21)$ & $3.5(0.22)$ \\
\hline $\begin{array}{l}\text { ヘッド高さ, in }(\mathrm{cm}) \\
\text { 温度, }{ }^{\circ} \mathrm{C}\end{array}$ & $95(241.3)$ & $84(213.4)$ & $84(213.4)$ & $86(218.4)$ & $77 \quad(195.6)$ & $72(182.9)$ \\
\hline 予備処理 & 420 & 430 & 420 & 410 & 440 & 410 \\
\hline ガス化炉（平均） & 907 & 926 & 887 & 904 & 829 & 834 \\
\hline " （最大） & 975 & 950 & 925 & 950 & 870 & 910 \\
\hline $\begin{array}{l}\text { 炭素変換率, \% } \\
\text { 生成ガス, 石炭 } 1 \mathrm{~b} \text { 当り }(\mathrm{kg})\end{array}$ & 67 & 70 & 72 & 74 & 77 & 71 \\
\hline $\mathrm{H}_{2}+\mathrm{CO}+\mathrm{CH}_{4}, \mathrm{ft}^{3}\left(\mathrm{~m}^{3}\right)$ & 17 (1.06) & $17(1.06)$ & 18 (1.12) & $16(1.00)$ & $17 \quad(1.06)$ & $16(1.00)$ \\
\hline $\begin{array}{l}\mathrm{CH}_{4}, \mathrm{ft}^{3}\left(\mathrm{~m}^{3}\right) \\
\text { ガス組成, } \%\end{array}$ & $3.9(0.244)$ & 1) $4.3(0.269)$ & $3.7(0.231)$ & 1) $4.2(0.262)$ & $3.6(0.225)$ & $3.0(0.187)$ \\
\hline $\mathrm{H}_{2}$ & 34 & 28 & 36 & 31 & 31 & 38 \\
\hline $\mathrm{CO}$ & 19 & 25 & 19 & 20 & 25 & 11 \\
\hline $\mathrm{CH}_{4}$ & 16 & 18 & 14 & 17 & 14 & 11 \\
\hline $\mathrm{CO}_{2}$ & 32 & 29 & 31 & 32 & 30 & 40 \\
\hline $\mathrm{CH}_{4}, \%\left[\mathrm{CO}_{2}+\mathrm{N}_{2}\right.$ を除く $]$ & 23 & 25 & 21 & 26 & 21 & 19 \\
\hline タール，\%[石炭に対して] & 2.9 & 6.0 & 3.4 & 6.0 & 1.4 & 3.3 \\
\hline
\end{tabular}

いる炉は，西ドイツに拈ける固定床式の Lurgi 法と 噴流床式の Koppers Totzek 法である。

(1) Lurgi 法 加圧固定床ガス化法で西ドイツの Lurgi 社が開発。 $800 \sim 1,200^{\circ} \mathrm{C}, 20 \sim 30 \mathrm{~kg} / \mathrm{cm}^{2}$, 単 機最大容量 $20 \sim 30 \mathrm{t} / \mathrm{hr}_{0}$. 1936年以来世界各国で50基以 上の実績を有する商業炉。

Lurgi 法は, 非粘結炭でかつ $3 \sim 30 \mathrm{~mm}$ の塊炭の 固定床ガス化を特徵とするが，現在西ドイッの Kellermann 発電所で 17 万W の複合サイクルのガス化 発電 (試験中) に, 南ア連邦 Sasol で Fischer Tropsch 合成により合成原料ガス拈よび原油製造に，また イギリス，韓国，チェコスロバキヤなどで広く実際
に使用されている。特 にSasol に打居業規模生 産は有名であり，世界各国で注目されるところとな っている。一方 Lurgi 法による SNG 向けのガス化 は,アメリカに拈いても注目されて牧り, 現在 $\mathrm{El}$ Paso Natural Gas が1978 年までに New Mexico 州 の北西部に 700 万 $\mathrm{m}^{3} / \mathrm{d}$ 規模のプラントの完成を決め たといわれている。この場合に Lurgi 炉は大型化が 困難であるために，ガス化炉を28基葟ど並べる必要が あると見込まれている。イギリスの Scottish Gas Board でも Westfield で 7 万䂔/d の SNG ガス化 試験が進められている。

(2) Koppers Totzek 法 常圧噴流床ガス化法で西 
表 10 Synthane 法（1974年）

\begin{tabular}{|c|c|}
\hline (1)テストプラント & \\
\hline 石炭処理量 & $3 \mathrm{t} / \mathrm{hr}(75 \mathrm{t} / \mathrm{d})$ \\
\hline 建設費 & 1,200 万 $\$$ \\
\hline ガス化炉ガス生産量 & $\begin{array}{l}10 \text { 万 } \mathrm{ft}^{3} / \mathrm{hr} \\
\left(240 \text { 万 } \mathrm{ft}^{3} / \mathrm{d}\right)\end{array}$ \\
\hline パイプラインガス生産量 & $\begin{array}{l}13,000 \mathrm{ft}^{3} / \mathrm{hr} \\
\left(30 万 \mathrm{ft}^{3} / \mathrm{d}\right)\end{array}$ \\
\hline 所要人員 & 約100名 \\
\hline (2)コマーシャルプラント & \\
\hline 所要建設費 2 億 \$ & \\
\hline 石炭処理量 & $\begin{array}{l}\text { 15, 000t/d } \\
\text { (Pittsburgh coal) }\end{array}$ \\
\hline パイプラインガス & 2.5 億 $\mathrm{ft}^{3} / \mathrm{d}$ \\
\hline プラントに必要な石炭総量 & 1 億 $\mathrm{t}$ \\
\hline 必要水量 & 2,800 万 $\mathrm{gal} / \mathrm{d}$ \\
\hline 副産物回収＼cjkstart硫黄 & $200 \mathrm{t} / \mathrm{d}$ \\
\hline B T X & 約 $30,000 \mathrm{gal} / \mathrm{d}$ \\
\hline 所要人員 & 約200名 \\
\hline $\begin{array}{l}\text { パイプラインガスの売值 } \\
\text { (石炭価格によって変動) }\end{array}$ & $\begin{array}{l}896 \sim \$ 1.00 \\
/ 1,000 \mathrm{ft}^{3}\end{array}$ \\
\hline
\end{tabular}

ドイッ Essen の Heinrich Koppers GmbH により 開発。 $1,500 \sim 1,800^{\circ} \mathrm{C}$, 常圧, 単機最大容量 2 バーナ 一炉 $16 \mathrm{t} / \mathrm{hr}, 4$ バーナー炉 $35 \mathrm{t} / \mathrm{hr}$ 。1949年以来世界 各国で25基以上の実績を有する商業炉。

Koppers Totzek 法は, どのような石炭でも使用 しうるが 200mesh 以下に微粉研する必要がある。 微粉炭の水蒸気と酸素とによるガス化法で, 主として $\mathrm{H}_{2}+\mathrm{CO}$ ガスが得られる。わが国でも1955年に常磐炭 のガス化により合成原料ガス製造用として使用された 実績がある。

アメリカに和沙るガス化発電向けの低カロリーガス 用としてのガス化法には次のようなものが開発中であ る。

(1) U gas 法 加圧流動床ガス化法で, シカゴの
IGT が開発中。ベンチスケール $4 \mathrm{ft} \phi \times 30 \mathrm{ft}$, 圧力 10 $\mathrm{kg} / \mathrm{cm}^{2}$ 。

（2） GE gas 法 加圧固定床ガス化法で，General Electric 社が開発中。 $500 \mathrm{~kg} / \mathrm{cm}^{2}$ 。

(3) WH 法 ドロマイト使用加圧流動床ガス化 法 で, Westinghouse Electric 社が開発中。 $550 \mathrm{~kg} / \mathrm{hr}$, $20 \mathrm{~kg} / \mathrm{cm}^{2}$ 。

(4) CE 法 常圧噴流床式ガス化法で, Combustion Engineering 社が開発中。 $5 \mathrm{t} / \mathrm{hr}$ 。

ガス化発電に和いては，ガス化炬に拉ける大容量か つクリーンなガスを取得する技術，材料開発技術など とともに，ガス化炉と発電プラントとの経済的かつ安 定的な協調運転技術の確立が，過給ボイラーめるいは 廃熱回収システムの開発とともに重要である。

もちろんエネルギー効率として考えるならば, 石炭 の直接燃焼方式も当然検討されなければならない問題 であろう。

以上のほかに, ソ連, アメリカなどに怙ける石炭の 地下ガス化, 西ドイッの Jülich 研究所に拉ける高温 原子炉の熱利用によるガス化技術の開発などがある。

\section{5. 石炭の液化}

5.1 石炭液化の一般的プロセス

石炭液化の一般的なプロセスは図 7 に示すと特りで ある8)。原料石炭はガス化とは異なり炭種への制限が あるが，理想的にはかっ炭あるいは歴青炭が対象とな る。これをできるだけ粉砕し乾燥したのちに, 溶剂, タールなどを混合して，油中粉砕などにより 60〜100 mesh (0.25 0.15mm) 以下に微粉砕しスラリー化す る必要がある。当時のドイッの Bergius 法では, $60 \mathrm{mesh}$ 以下 $80 \%$ 程度に粉研することを基準にして いたといわれる。スラリー化の際に触媒を加える場合 もある。この石炭スラリーに対して直接水添分解する 直接液化が行なわれる。

一方, タールなどの溶剤を混合して, 抽出液化した

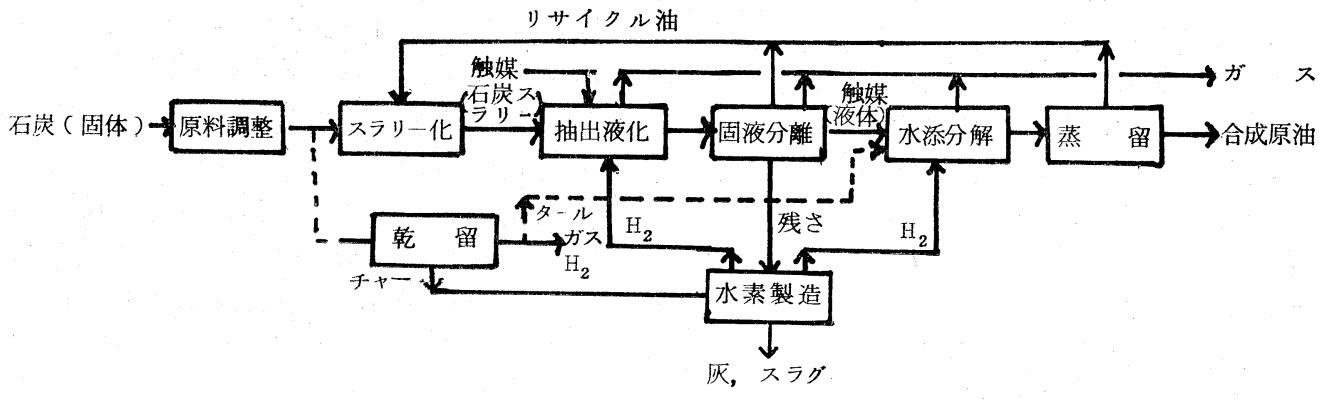

図 7 石炭液化の一般プロセス 
後に固液分離を行ない抽出物を水添分解する場合, 点 線にて示すように, 原料石炭を調整して乾留し, 水素 化が比較的容易な乾留タールを光てこれを直接水添分 解する場合もある。また最近では軽度の水素化分解あ るいは熱分解することによって, 石炭中の液化しやす い部分のみをえて，これを合成重質油としてとり出す 方法抒よびこれをさらに2 次液化する方法る採用され ている。すなわち最近注打る液化技術の開発は, 従 来の直接液化法のみではなく, 石炭中の水添分解しや すい部分のみを抽出するかあるいは乾留によって乾留 タールをえてこれを液化する方法が採用されている。 な敃低温乾留タールの水添分解はわが国でも過去に実 施されている。

混合油はテトラリンなどの試薬や石炭タールの高沸 点留分などが好適とされているが, 最近では石油重質 油, アスファルトなども使用されている。工業的には 液化反応によって生成される油を循環油として使用す ることが，混合油対策として理想的である。混合油は 石炭を溶解して膨潤化すると同時に, 水素供与体とし て, 石炭質をアスファルト質に変換させて液化反応を 促進させる效果がある。一般に，直接液化法の場合に は, 混合油の性状, 触媒の性状, 添加量などによって 異なるが，混合油中の石炭濃度は $40 \sim 50 \%$ 程度であ り, 溶剤抽出法では 石炭に対して $2 \sim 5$ 倍程度であ る。

水素化に括ける触媒の開発もまた重要である。一般 には $\mathrm{Co}, \mathrm{Mo}, \mathrm{W}, \mathrm{Sn}, \mathrm{Fe}$ などの酸化物, 八口ゲ ン化物などが効果的であるといわれている。通常工業 的には塩化亜鉛, 塩化スズ拉よびより安価な酸化鉄ま たは硫酸鉄，とくに使い捨てができる赤泥などが使用 される。

反応条件はガス化の場合よりも一般に，圧力が高く $200 \sim 500 \mathrm{~kg} / \mathrm{cm}^{2}$, 温度は低く $400 \sim 500^{\circ} \mathrm{C}$ 程度であ る。最近では圧力 $20 \sim 70 \mathrm{~kg} / \mathrm{cm}^{2}$, 温度 $420 \sim 450^{\circ} \mathrm{C}$ 程度に和ける比較的温和な条件下に抽出液化した後に 固液分離を行ない, よりクリーンな合成重質油を取得 する方法もとられている。

一般的には, 炭種, プロセスに最適な水添反応条件 の設定, 触媒の開発特よび装置の安全化, 自動化, 大 型化などが問題となる。

残渣あるいは乾留によるチャーは, 発電用あるいは 水性ガス化反応により水素製造に向けられる。

石炭の液化に和ける炭種の選定は重要である。組織 成分による影響も大きい。なぜならばイナーチニット グループに代表されるフジニット，ミクリニットなど
の微細組織成分の含有量が高い石炭では, 液化率がよ り一層低くなるからである。また例觉ば，石炭化度と 水素添加に上る液化率との関係比ついてみれば, 液化 率の最大值を示す石炭は C 85 ８8％(daf) 付近にあ ることはよく知られている。この付近の液化に最適な 石炭は, 水素含有量が高く, ピリジン抽出量の極大值 挌よびギーセラープラストメーターの最高流動度, 一 次タール収量の極大值なぞの物理, 化学的な物性の転 位点ともよく一致するいわゆる粘着炭の領域に相当し ている。

この意味では，わが国に産出する代表的な日本炭で ある三池炭, 夕張炭などの粘着炭は, 外国炭に比較し て組織学的にイナーチニットグループが少なくかつ水 素含有量が高い石炭であるので, もっとも液化に有利 な石炭であるといえる。従って, このような特徴を持 った貴重な日本炭の生産は, バインダー的性格を持つ 乾留用原料炭の配合用基炭でもあるので, 恒久的に確 保されなければならないとい光よう。しかし海外から 石炭を輸入する場合，コークス用原料炭との関連がで てくるので, この意味ではガス化と同様に原料炭以外 の一般炭を考慮する必要があるう。

前述したように, 石炭類の $\mathrm{H} / \mathrm{C}$ (原子比) は原油, ガソリンのそれに比して低いので, 石炭を液化する場 合には, 炭種の選定に伴ら水素の消費量が問題とな る。と同時にどこからどのような形で水素を確保する かが特に問題となってくる。

液化法をプロセス別に分類すると次の 4 種類があ る。

（1）直接水添液化法 例えば Bergius 法, H coal 法, Synthoil 法

（2）乾留水添液化法 例兄ば COED 法, Toscoal 法

（3）抽出水添液化法 例えば Pott Broche 法, CSF 法, SRC 法

(4) 合成液化法例觉ば Fischer Tropsch 法

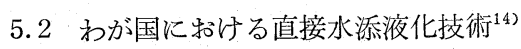

Bergius 法を発展させた当時のドイツと同様に, 石 油資源に不足するわが国では石炭の直接水添液化によ る人造石油の製造開発が古くより積極的に官民協力の もとに進められていた。すなわち1921年当時の海軍燃 料廠によって研究開発が始められたが, 基礎研究, ㅇ イロットプラント試験などとともに，実際に日本炭を ドイッに送付した試験も実施された。これらの結果を ベースにして1936年海軍燃料廠德山に96式水素添加装 置が完成されるに至っている。 
一方, 同年に当時の北朝鮮の日本窒素肥料の子会社 である朝鮮人造石油(株)の阿吾地工場に, かっ炭であ る阿吾地炭を原料として, 石炭処理量 $110 \sim 120 \mathrm{t} / \mathrm{d}$, 温度 $440 \sim 445^{\circ} \mathrm{C}$, 水素圧力 $220 \mathrm{~atm}$, 触媒 $\mathrm{Fe}(\mathrm{OH})_{3}$ 十硫黄の直接液化工場が, また当時の満鉄（南満洲鉄 道(株)）の撫順炭鉱に，瀝青炭である大山炭を原料と して, 石炭処理量 $52 \mathrm{t} / \mathrm{d}, 410^{\circ} \mathrm{C}, 200 \mathrm{~atm}$, 触媒 $\mathrm{FeS}$ の工場がそれぞれ建設されるに至った。

これらの 3 工場はドイッと同様に艺孔杂れ改良が加 えられたが，1945年第 2 次大戦終戦時まで幾多の障害 をのりこえて, 航空然料生産のための努力が熱心に続 けられた。

陸軍燃料廠との関連に和いては，1929年頃より三菱 鉱業(株)が当時の北樺太のかっ炭である内幌炭を対象 として,オートクレーブによる基礎研究を実施してい た。この結果をべースにして1934年研究所内に内容積 $80 l, 400^{\circ} \mathrm{C}, 200 \mathrm{~atm}$ の半工業規模装置を建設 し試験 を進めている。ちなみに陸軍当局の要望により，1939 年内幌炭の低温乾留タールを原料とする液化によって 製造された航空揮発油約 8 ドラムが，陸軍によるエン ジン試験の結果が良好であったので，これによる実際 の飛行テストが，わが国では初めて立川飛行場と三菱 鈗業大宮研究所との間で行なわれたといわれる15)。

以上の上うに, 当時の装置材料, 計器特よびェンジ ニヤリングなどに未発達の部分があったであるらこと は想像されるところであるが，これらを克服してそれ ぞれわが国独自の反応装置、プロセスなどが開発され

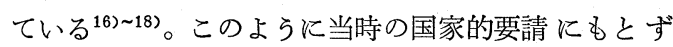
き, 石炭からの航空燃料生産に向って努力之苦心を重 衫らた多くの先輩達の貴重な業績や考方方は, いま やエネルギー危機を迎光た今日，ふたたび注目され見 直されようとしている。

この頃わが国に沶いては，さらに然料研究所（現在 の公害資源研), 理化学研究所, 満鉄中央研究所, 八 幡製鉄所, 三井鉱山三池工場，三菱鉱業研究所など で, 開発試験がきわめて精力的に行なわれており貴重 な報告が数多く提出されている。

戦後はしばらくの間研究中止の状態にあったが，石 炭の構造解析劣るいは石炭利用拡大を目標とした液体 燃料, 芳香族ケミカルズなどを志向して1956年ごろよ りふたたび研究開発が始められた。すなわち，1956年 資源技術試験所では三池炭処理量 $60 \mathrm{~kg} / \mathrm{d}$ のテストプ ラントを建設し，三井鉱山括よび三池合成工業(株)も 参加して1961年末で研究が進められた。同年北海道大 学ではペースト送入量 6 10l/hr のテストプラント
による主として北海道炭についての研究が開始され， また北海道工業開発試験所でも, 基礎研究が進められ た。さらに1958年北海道炭鉱汽船(株)では石炭処理量 $1 \mathrm{t} / \mathrm{d}$ を戸田の研究所内に建設, 三池合成でも石炭水 素化分解生成油の 2 次改質として1956年に中油分の気 相改質プラント $240 l / \mathrm{d}$ を建設, それぞれ試駼研究が 進められている。もちろん, 東大, 京大など各大学に 特訬る基礎的研究も実施されている。

しかしながら, 石炭の液化は, この頃から始まった 豊富かつ安価な石油による世界的なエネルギー流体化 の波に押されて，いずれる工業化への進展を及ないる まに中断されるに至り現在に至っている。

5.3 最近飞扮汀る液化技術8) 133, (19) 233

アメリカに打いて熱心に開発が進められているが, 主なるものをあげると次のと打りである。

(1) CSF 法 石炭抽出と次段の 水素化とを組及合 わせた抽出水添法で Consolidation Coal 社が開発 中。石炭処理量 $20 \mathrm{t} / \mathrm{d}$, 温度 $390 \sim 400^{\circ} \mathrm{C}$, 压力 $35 \mathrm{~kg}$ $/ \mathrm{cm}^{2}, 2$ 次水添は $\mathrm{H}$ oil 法により $430 \sim 440^{\circ} \mathrm{C}, 210$ $\mathrm{kg} / \mathrm{cm}^{2}, \mathrm{Co}-\mathrm{Mo}-\mathrm{Ni}$ 系触媒, 1970年に中止。

(2) H coal 法 Bergius 法々同様の直接水添法で Hydrocarbon Research 社が開発中。3t/d, 450 500 ${ }^{\circ} \mathrm{C}, 150 \sim 180 \mathrm{~kg} / \mathrm{cm}^{2}$, Co-Mo 系触媒。

（3）Synthoil 法 固定床触媒層による直接水添法 で Pittsburgh Energy Research Center が開発中。 $0.5 \mathrm{t} / \mathrm{d}, 450^{\circ} \mathrm{C}, 140 \sim 280 \mathrm{~kg} / \mathrm{cm}^{2}, \mathrm{Co}-\mathrm{Mo}$ 系触媒 (ペレット), 現在 $10 \mathrm{t} / \mathrm{d}$ を建設中。

(4) $\mathrm{COED}$ 法 $3 \sim 5$ 段の流動床低温乾留を行な い, 生成タール, 軽油を水素化する多段流動乾留水添 法で成型コークスで知られる Food Machinery 社が 開発中。 $36 \mathrm{t} / \mathrm{d}, 430 \sim 550^{\circ} \mathrm{C}$, 常压, 2 次水添は 370 $\sim 430^{\circ} \mathrm{C}, 120 \sim 175 \mathrm{~kg} / \mathrm{cm}^{2}, \mathrm{Ni}-\mathrm{Mo}$ 系触媒。

（5） SRC 法 無灰，無硫黄のいわゆる溶剤精製炭 （SRC）を製造する溶剤抽出液化法で Gulf Oil 系の Pittsburgh \& Midway Coal Mining 社が開発中。 軽質油をらる場合にはさらに SRCを2次水添する。 $50 \mathrm{t} / \mathrm{d}, 400 \sim 480^{\circ} \mathrm{C}, 70 \mathrm{~kg} / \mathrm{cm}^{2}$, 無触媒 (2 次水添は $\mathrm{H}$ oil 法により $210 \mathrm{~kg} / \mathrm{cm}^{2}$ )。

$\mathrm{SRC}$ の融点 $180^{\circ} \mathrm{C}$, 発熱量 $9,000 \mathrm{Kcal} / \mathrm{kg}$ 。

(6) Exxon 法 Donor Solvent 法ともいわ机る溶 剂抽出水添法で Exxon 社が開発中。1t $/ \mathrm{d}, 450^{\circ} \mathrm{C}$, $140 \mathrm{~kg} / \mathrm{cm}^{2}$, 無触媒, 固液分離後 2 次水添, 現在 $250 \mathrm{t}$ /d を計画中 (1979年スタート予定)。

例えば Synthoil 法は図 8 に示すと打りで, 内径 $7.9 \mathrm{~mm} \phi$, 長さ $21 \mathrm{~m}$ という細長い反応管中に, 石炭 


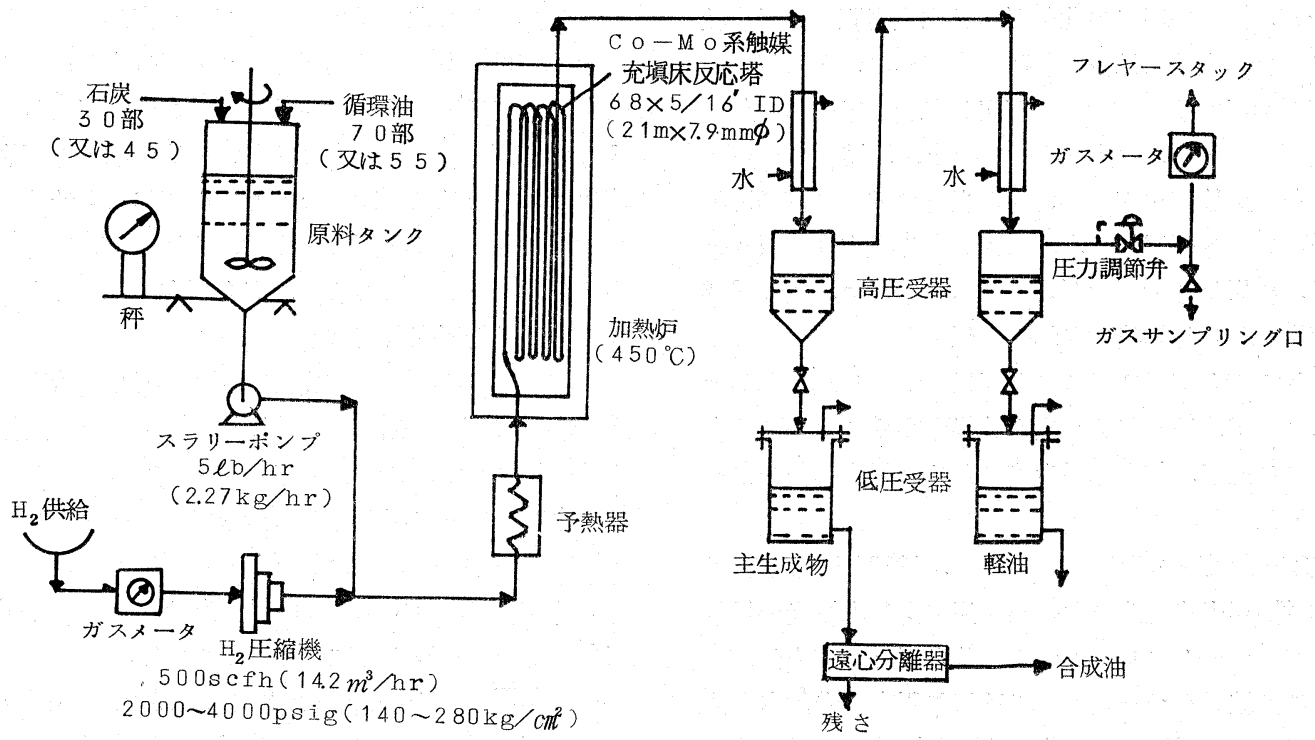

图 8 Synthoil 法

表 11 Synthoil 法の結果

\begin{tabular}{|c|c|c|c|c|c|}
\hline \multirow[b]{2}{*}{ 压 力 (psi) } & \multicolumn{3}{|c|}{ Kentucky 炭 } & \multicolumn{2}{|c|}{ Indiana No. 5 炭 } \\
\hline & 4,000 & 4,000 & 4,000 & 4,000 & 2,000 \\
\hline 炭 / 循 環 油 & $30 / 70$ & $30 / 70$ & $45 / 55$ & $30 / 70$ & $30 / 70$ \\
\hline スラリー送り速度 $\quad\left(\mathrm{lb} / \mathrm{hr} / \mathrm{ft}^{3}\right)$ & 140 & 140 & 140 & 140 & 140 \\
\hline 水 素 流 & 500 & 125 & 125 & 500 & 500 \\
\hline 実 験 時 間 (hr) & 200 & 155 & 20 & & \\
\hline 硫 石 炭 中 $(\%)$ & 4.6 & 4.6 & 4.6 & 3.9 & 3.9 \\
\hline 循 環 油 中 $(\%)$ & 0.48 & 0.34 & 0.19 & 0.6 & 0.6 \\
\hline 黄 混 合 油 中 $(\%)$ & 1.72 & 1.62 & 2.17 & 1.41 & 1.41 \\
\hline 生組 ペンタン可溶分 & 62.9 & 68.7 & 79.5 & $82.1^{*}$ & $69.2^{*}$ \\
\hline 告成）アスファルテン & 24.8 & 23.4 & 17.4 & 9.1 & 17.9 \\
\hline 油成 ベンゼン不溶 分 & 9.8 & 6.4 & 2.1 & 8.8 & 12.9 \\
\hline (灰 分 & 2.5 & 1.5 & 1.0 & & \\
\hline 生元 & 88.8 & 89.2 & 89.9 & 90.4 & 92.3 \\
\hline 成素 & 7.8 & 8.5 & 9.2 & 7.8 & 6.5 \\
\hline 油西 & 1.1 & 0.8 & 0.6 & 0.4 & 0.8 \\
\hline$(\%)(\cdots$ & 0.49 & 0.35 & 0.19 & 0.30 & 0.42 \\
\hline \multirow{2}{*}{$\begin{array}{l}\text { 生成油粘度 }\left(180^{\circ} \mathrm{F}\right)(\mathrm{SSF}) \\
\text { 生 成 油発熱量 }(\mathrm{Btu} / \mathrm{lb})\end{array}$} & $152-534$ & $77-274$ & $21-30$ & & \\
\hline & 16,700 & 17,200 & 17,700 & & \\
\hline
\end{tabular}

（注）*はヘキサン可溶分

: タール比 $=45: 55$ のスラリーを水素流速 $2 \mathrm{~m} / \mathrm{s}$ と いら大量の水素とともに通して, 激しい攪拌による反 応を行なわせたのちに, 生成物を固液分離して高硫黄 の石炭より低硫黄の燃料油を製造する方法である。1 $\mathrm{t}$ の麻青炭より約 $3.0 \sim 3.3 \mathrm{bbl}$ の油が取得できる。 反応条件特よび生成油の性状例は表11に示すと特りで ある。

現在 $0.5 \mathrm{t} / \mathrm{d}$ 規模の試験そ実施中で，ガス化に和け 
表 12 Synthoil 法における合成原油価格（1975年） $(108,000 \mathrm{bbl} / \mathrm{d}$ のプラント規模, 収率3〜 $3.3 \mathrm{bbl} /$ 石炭 $\mathrm{t}$ )

\begin{tabular}{cc}
\hline 原料石炭コスト & 合成原油販売価格 \\
\hline $8 \$$ & $7.52 \$ / \mathrm{bbl}$ \\
10 & 8.33 \\
12 & 9.14 \\
20 & 12.38 \\
\hline
\end{tabular}

る Synthane 法とともに Pittsburgh Energy Research Center ではもっとも力が入れられている方法 である。

ごく最近の情報によれば, Synthane 法の隣接地に 反応管内径 $10 \mathrm{~cm}, 10 \mathrm{t} / \mathrm{d}$ 規模のパイロットプラント が建設中であるといわれている。合成原油製造価格は Dr. Yavorsky 飞よれば表12のと拈りで，脱硫重油と 十分競合しうるものと予想されている5゙。

COED 法の概要は図 9 亿示すと打りで，その建設 コスト抢よび経済性試算は表13のと打りである。合成 原油は実際に駆逐艦用燃料として運転試験されたこと が報道されて和り，Synthoil とともに順調に開発が 進められているように思われる。SRC 法, Exxon 法 も注目されるところである。

以上のほか飞, ドイッ,イギリス, 南ア連邦, オー ストラリアに掠いても, 石炭の液化に関する試験が進
められて和り, 特に溶剤抽出水添法に関する技術開発 が重点として検討されている。

\section{6. わが国における技術開発 ${ }^{122}$}

1973年末のいわゆる石油危機以来, わが国でもふた たび石炭エネルギーの必要性が見直されるに至り，石 炭のガス化, 液化による流体エネルギーへの転換が, その技術開発がサンシャイン計画として注目されるに 至ったことは前述したと招りである。

石炭のガス化について概要を示すと, 現在石炭のガ ス化咯よびプラズマガス化汇関する基礎研究が国立研 究所特よび大学に括いて実施されている。民間への委 託費による技術開発としては, 水添加圧流動床ガス化 法が(株)日立製作所と三藤鉄工(株)で，溶融床ガス化 法が三菱重工業(株)と新明和工業(株)飞拈いて, また ガス化発電に関する技術開発は石炭技研が中心となっ て，それぞれ強力に推進されつつある。

以上のほかにテクノロジーアセスメント, $7,000 \mathrm{~m}^{3} /$ $\mathrm{d}$ 規模（石炭処理量 $15 \mathrm{t} / \mathrm{d}$ ) の流動床ガス化プラント の概念設計などについて検討が進められて括り，今後 におけるこの方面の発展が期待されている。

石炭の液化に叔る新しい技術開発の課題として は, 直接水添液化法と抽出水添液化法が特に注目され ている。

直接水添液化法は, 従来ガソリンなどの合成石油の 製造を目的として実施されたことは前述したと括りで

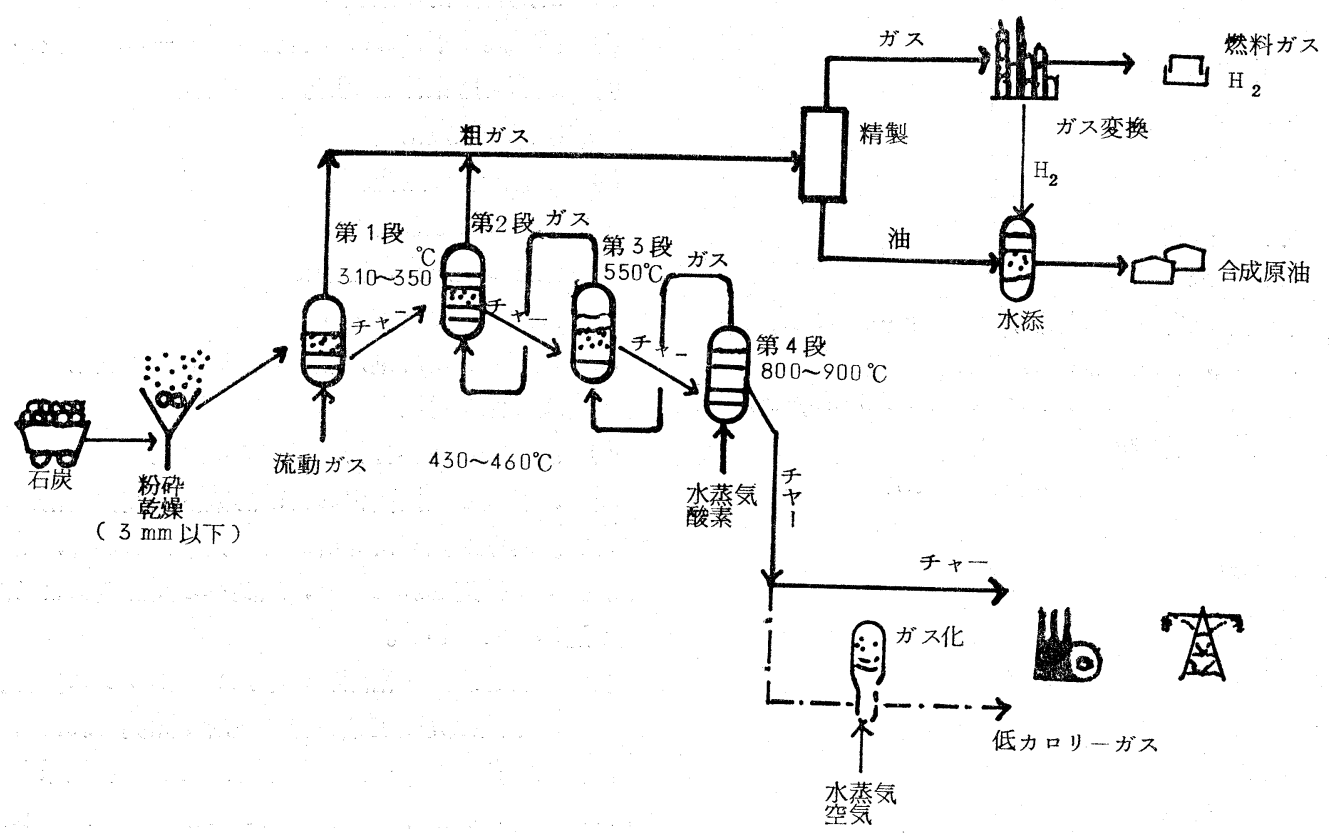

図 9 COED 法 
あるが，今回は主として合成原油ないし燃料油の製造 技術開発を目標にしている。このために石炭ペースト

表 13 COED 法（1973年）

\begin{tabular}{ll}
\hline (1) 建設コスト & 500 万 $\$$ \\
完成 & 1970 年 8 月 \\
操業コスト & 320 万 $\$ / \mathrm{yr}$ \\
規模 & $36 \mathrm{t} / \mathrm{d}$ \\
オイル生産量 & $1.1 \mathrm{bbl} / \mathrm{t}$ \\
ガス生産量 & $16,000 \mathrm{ft}^{3} / \mathrm{t} \quad\left(400 \mathrm{Btu} / \mathrm{ft}^{3}\right)$ \\
チャー生産量 & $1, \mathrm{co0lb} / \mathrm{t}$ \\
人員 & 47 名
\end{tabular}

(2) コマーシャルプラント

$\begin{array}{ll}\text { 所要費用 } & 1 \text { 億 } 1.5 \text { 億 } \$ \\ \text { 石炭使用量 } & 24,000 \mathrm{t} / \mathrm{d} \\ \text { オイル生産量 } & 26,400 \mathrm{bbl} / \mathrm{d} \\ \text { ガス生産量 } & 3.9 \text { 億 } \mathrm{ft}^{3} / \mathrm{d}\left(400 \mathrm{Btu} / \mathrm{ft}^{3}\right) \\ \text { チャー生産量 } & 12,000 \mathrm{t} / \mathrm{d}\end{array}$

(3) 経済性試算 (合成原油, チャー, $\mathrm{H}_{2}$ の場合) ベース 歴青炭 $25,000 t / d$ (dry) $22 \varnothing$

$/ 100$ 万Btu $(6 \$ / t)$

合成原油 $32,800 \mathrm{bll} / \mathrm{d}, 6.15 \$ / \mathrm{bbl}$

$\mathrm{H}_{2} \quad 2.2$ 億 $\mathrm{ft}^{3} / \mathrm{d}, 50 \% / 1,000 \mathrm{ft}^{3}$

チャー $13,750 \mathrm{ft} / \mathrm{d}, 22 థ / 100$ 万 Btu

$(5.6 \$ / \mathrm{t})$,

100 万 $\$(1973)$

$\begin{array}{cr}\text { 固定資本費 } & \$ 139 \\ \text { 運転費 } & 14 \\ \text { 計 } & 153\end{array}$

年間製造コスト

$\begin{array}{lr}\text { 石炭費 } & 50 \\ \text { その他製造コスト } & 41 \\ \quad \text { 計 } & 91 \\ \text { 年間販売費 } & 121 \\ \text { 年間利益 } & 30\end{array}$

（4）経済性試算（合成原油,低カロリーガスの場合） 瀝青炭, 合成原油は前と同様

低カロリーガス 16.5 億 $\mathrm{ft} / \mathrm{d}\left(200 \mathrm{Btu} / \mathrm{ft}^{3}\right)$ $64 \varnothing / 100$ 万 Btu

100 万 $\$(1973)$

固定資本費 196

運転費 13

計 209

年間製造コスト

石炭費 50

その他の製造コスト 46

計 96

年間販売費 $\quad 137$

年間利益
量 $2 \mathrm{t} / \mathrm{d}$, 合成原油 $1,600 l / \mathrm{d}$ 規模の液化装置を1983年 頃までに開発する方向で最適プロセスの技術開発が進 められている。

溶剤抽出水添法は, まず液化扣よびガス化などの原 料として, 杰た直接燃焼, 炭素材料の原料としても最 適と思わ饥る無灰無硫黄である溶剂処理炭 (STC, Solvent Treated Coal) の製造技術の確立が図られ る。このために1981 年頃を目標に 石炭処理量 $30 \mathrm{t} / \mathrm{d}$, STC $5 \mathrm{t} / \mathrm{d}$. 規模の技術開発が進められている。続い て STC の 2 次水添液化法の確立を図るための技術開 発も進められる計画になっている。

すなわち従来は, 高度に水素化することによって， すなわち Bergius 法による直接液化によってガソリ ンなどの軽質油をらる方向に, あるいは芳香族ケミカ ルズを取得する方向にあったが, 現在に拉ける研究開 発の重点は, 重質油程度にとどめてできるかぎり水素 の消費量を少なくすると同時に, 石炭構造中で抽出し やすい部分のみを取り出し分離することによってクリ ーンな重質油を得る技術開発が進められている。もち ろん, 必要があればさらにこれを 2 次水添するかある いは高度の直接水添により,より軽質化されたクリー ンな軽質油あるいは種々の芳香族ケミカルズをらる場 合もありらる。

石炭の液化の最適技術開発に当たっては, 次のよう な課題があり，解決すべき問題点が多くある ${ }^{24)}$ 。

(1) 前処理技術の確立

(2) 高温高圧下に括ける石炭スラリーの取り扱い

(3) 最適反応条件と反応装置の確立

(4) 固液分離技術

（5）水添触媒の開発

(6) 炭種による影響

（7）装置の安全化, 自動化

(8) 装置のスケールアップ

（9）残椬および溶剤，触媒の回収および利用

(10) 環境保全対策

(11) 関連する金属材料, バルブの開発

現在, 石炭の直接液化拈よび溶剤抽出液化技術に関 する基礎研究が国立研究所および大学において, それ ぞれ強力に推進されており，民間への委託費による開 発も進められている。

特に注目される技術開発の中にソルボリシス液化法 がある。本法は九州工業開発試験所で開発されたもの で, 従来溶剤として一般に使用されていた石炭系タ一 ルに対して, 石油系重質油を用いて常圧でしかも水素 なしで熱処理を基本とする溶剤抽出法である。一般に 
石炭と重質油との混合物は, 炭化初期段階に和いてメ ソフェーズの小球体が発生することを確認している が，この小球体を分離除去することによって無灰低硫 黄のピッチあるいは重質油が得られるわけである。本 法は現在三菱重工業(株)によってミニプラント試験が 進められよらとしている。軽質油をらるためには，さ らに 2 次水添が必要であることは SRC 法の場合と同 様である。

この意味では，わが国ですでに開発された優れたプ ロセスの一つである馬場有政による膨潤炭法も今後注 目されるべき方法であるとい方ら。

一方わが国に括沪る Gulf Oil 系の SRC 法につい ては現在三井コンソシアムである 三井 SRC 研究共 同体が大牟田地区に石炭処理量 $5 \mathrm{t} / \mathrm{d}$ 規模のパイロッ トプラント建設を計画中であることが伝えられてい る。住友石炭(株)においては赤平地区に $2 \mathrm{t} / \mathrm{d}$ 規模の 溶剂抽出液化技術の開発が順調に進められている。い ずれも今後の発展が期待されるところである。

\section{7.おわりに}

エネルギー資源輸入国であるわが国としては, エネ ルギーの分散化，多様化を図る必要があり，石炭の再 見直しによる再利用を前向きに検討する必要がある。 このためには, 従来から盛んに利用されている乾留に 加えて, 石炭のガス化, 液化によりクリーンフューエ ルとする流体化への転換技術の開発を積極的に進める 必要がある。もちろん，このなかに石炭の直接然焼， 流動床燃焼, 石炭に種々の溶剂, 重質油を加えたコロ イド然料なぞによるエネルギー確保, 電力への 2 次エ ネルギーへの転換もまた重要である。

わが国に和ける石炭利用によるエネルギーあるいは 合成化学原料, 工業材料などへの確保の形態として は，国内で国内炭あるいは輸入炭を，単独もしくは両 者の混合において処理すること,さらには石炭と重質 油, サンドオイル，都市廃棄物などとの混合に扣いて 処理することによって，流体化あるいは原材料化する 方式と, 進んで海外に和ける産炭地あるいは最適地に 扣いて種々の形に流体化し, 流体化された LNG, メ タノール, 合成原油, 溶剤処理炭, コロイド然料など を輸送する方式とが考えられる。この場合に輸送性, 経済性の観点からみて, ごく当面はコロイド然料, 溶 剂処理炭などの輸入が最適のよらに思われる。原料石 炭としてはコークス用原料炭との関連もあるので, 原 料炭以外の 2 号炭あるいは一般炭が対象とするものと 考えられるが，いずれの場合においても，この時の資 源保有国との協調あるいは経済性, 安全性, 輸送性,
最適地などによって種々異なるものがあるであろら。 いずれにしても，わが国は将来にわたって資源の輸 入消費国であり，これを利用して付加価值を増大させ ていくべき国であることには変りないものと思われる ので, エネルギーの備蓄, 省エネルギー, 省資源対策 もさることながら，エネルギー資源の分散化，多様化 を積極的に推進すべき時にきたといえる。一方では, こうした技術開発を通じてわが国の将来の発展の基盤 を築き上げるために，世界的に資源豊富でかつ広く分 散して賦存している石炭資源の利用対策に対するより 多くの優れた若い技術者の養成, 確保, 拡大を今から 熱心に図るべき時にきたといえよう。

\section{文献}

1）木村英雄, 日本コークス協会誌, No. 5, 1 No. 6,8 (1976)，先端技術，2，443 (1974)

2) サンシャイン計画推進本部, 工業技術, 9, 8 (1975)

3) OCR, ERDA Report

4) 木村英雄, 日本鉱業会誌，87，1005 (1971)

5) I. Wender, P.M. Yavorsky, Y.C.Fu, ERDA, Pittsburgh Energy Research Center, 公資研に て講演, 11月（1975）

6) 日本経済新聞,（昭51.8.23）

7）小沢篤二, 燃協誌, 54, 132 (1975)

8) 木村英雄, 化学工学協会 CE シリーズ講習会(6), C -40 (1975)

9）科学技術庁，資源調査所報告第65号（昭48.11）

10）通産省，産業技術審議会エネルギー技術特別会報 告 (昭49.1)

11）日本産業技術振興協会, JITA =ュース, 7(1974)

12）同上, 調査報告書（昭49.2）

13) OCR, U.S. Department of the Interior, Annual Report (1974)

14) 三井啓策, 山口昌三, 触媒化学，1 (1939) 尚賢堂

15）三菱金属中央研究所50年の歩み, p160 (昭43.2)

16）柴田健三，燃協誌，31，267 (1953)

17) 森田穣, 化学工学, 40, 146 (1976)

18）森川清, 石油学会誌, 18, 377, (1975)

19）大内公耳, 燃協誌, 53, 83 (1974)

20）長哲郎, 功刀泰碩, 石油学会誌, 17, 869 (1974)

21）神谷佳男, 燃協誌, 55, 79 (1976)

22) 坂部孜, 石油学会誌, 17, 30 (1974)

23）森田義郎, 然協誌, 54, 22 (1975)

24）木村英雄, 化学経済研究所特別調査報告, 第 3 部 1 (1975) 


\title{
Gonversion into Fluid Phase and Direct Liquefaction of Coal
}

\author{
by Hideo Kimura
}

(National Research Institute for Pollution and Resources)

SYNOPSIS : - It is well known that the coal has the largest reserves and distribution in the energy resources of the world.

Since the energy crisis the coal utilization has come to be noteworthy again. For the use of coal, it is necessary to convert the polid into the fluid sulstances by means of the gasification and the liquefaction of coal.

The outline of the Sunshine project in Japan and the energy independence project in U.S.A. is described from the various viewpoints of the coal utilization.

Both the direct liquefaction and the solvent extraction liquefaction are attracted notice in the fieled of coal conversion in Japan. 